\title{
Photocatalytic discolouration of Reactive Black 5 by UV-A LEDs and solar radiation
}

\author{
Jorge Rodríguez-Chueca ${ }^{a}$, Leonor C. Ferreira ${ }^{a}$, José R. Fernandes ${ }^{b, c}$, Pedro B. Tavares ${ }^{a}$, \\ Marco S. Lucas ${ }^{\mathrm{a}, *}$, José A. Peres ${ }^{\mathrm{a}}$ \\ a Centro de Química de Vila Real, Departamento de Química, UTAD-Universidade de Trás-os-Montes e Alto Douro, 5000-801 Vila Real, Portugal \\ ${ }^{\mathrm{b}}$ Departamento de Física, UTAD-Universidade de Trás-os-Montes e Alto Douro, 5000-801 Vila Real, Portugal \\ ${ }^{\mathrm{c}}$ INESC-TEC, Rua do Campo Alegre, 687, 4169-007 Porto, Portugal
}

\section{A R T I C L E IN F O}

\section{Article history:}

Received 22 July 2015

Received in revised form 13 October 2015

Accepted 14 October 2015

Available online 17 October 2015

\section{Keywords:}

RB5 dye

UV-A LEDs

Photocatalysis

Solar radiation

Discolouration

\begin{abstract}
A B S T R A C T
One of the most important disadvantages of photocatalytic treatments is the high cost associated with the use of UV lamps. In this work, the efficiency of two UV-A LEDs (ultraviolet-a light emitting diodes) photosystems as a low cost alternative to conventional UV lamps was tested. The efficiency of the two UV-A LEDs photosystems was compared to that of the most economical UV source-solar radiation. To this end, the oxidative discolouration of Reactive Black 5 (RB5) aqueous solutions was studied using photocatalysis with different concentrations of $\mathrm{TiO}_{2}(0.5-1 \mathrm{~g} / \mathrm{L})$ and $\mathrm{H}_{2} \mathrm{O}_{2}(1.76,4.41,8.82$ and $17.64 \mathrm{mM})$, exposed to different radiation sources: UV-A LEDs and solar radiation. The use of $\mathrm{H}_{2} \mathrm{O}_{2}$ increased the discolouration rate of RB5; however, an excessive dosage reduced the yield of the treatment, and the best results were attained with a concentration of $8.82 \mathrm{mM}$ of $\mathrm{H}_{2} \mathrm{O}_{2}$. Strong differences were observed between the use of UV-A LEDs $\left(23 \mathrm{~W} / \mathrm{m}^{2}\right)$ and solar radiation. In both cases total discolouration was observed, but the discolouration rate was considerably higher with solar radiation. However, the use of a more powerful UV-A LED photo-system $\left(85 \mathrm{~W} / \mathrm{m}^{2}\right)$ allowed the achievement of higher discolouration rates $\left(k=0.284 \mathrm{~min}^{-1}\right)$ than those obtained with solar radiation $\left(k=0.189 \mathrm{~min}^{-1}\right)$ using only $0.5 \mathrm{~g} / \mathrm{L}$ of $\mathrm{TiO}_{2}$. Therefore, UV-A LED radiation is a serious alternative to conventional UV lamps, since they are ecofriendly, have a low operational cost and high energy efficiency.
\end{abstract}

(c) 2015 Elsevier Ltd. All rights reserved.

\section{Introduction}

The release of wastewaters into natural environments is very problematic to aquatic life [1] and mutagenic to humans [2]. Although many industries including the paper, cosmetics, and pharmaceutical industries are a source of polluted effluents [3,4], the textile industry is one of the largest consumers of water and generates a high amount of effluents containing a variety of pollutants, of which the dyes and pigments are the most significant. It is estimated that about $15 \%$ of the total world production of dyes is released and lost in textile effluents during the dyeing process [5].

Currently, there are more than ten thousand different dyes and pigments available on the market, and several different groups can be distinguished-for example, reactive, direct, vat, sulphur and azo dyes. Approximately $70 \%$ of dyes used in textiles industries

\footnotetext{
* Corresponding author.

E-mail address: mlucas@utad.pt (M.S. Lucas).
}

contain azo dyes with one or more azo bonds. These dyes are characterized by a strong fragrance and vivid colours, as well as high solubility, stability and, most importantly, a simple dyeing procedure [6]. Azo bonds can break under reducing conditions, resulting in different kinds of amines. Some of these aromatic amines are considered carcinogenic, and for this reason, they are limited by European legislation [7].

In recent years, several research groups have focused on the application of advanced oxidation processes (AOPs) in the treatment of textile wastewater as a serious alternative to conventional technologies [8,9]. AOPs are based on the generation of highly reactive oxygen species (ROS), such as hydroxyl radicals, which are able to destroy organic pollutants and pathogenic germs. Photocatalysis has been studied by several authors in the removal of: dyes [8,10-13]; persistent pollutants as pesticides [14,15]; antibiotics and medicines [16,17]; and microorganisms present in water and wastewater [18,19]. Titanium dioxide $\left(\mathrm{TiO}_{2}\right)$ is the most studied semiconductor in photocatalysis, due to its high photoactivity, low cost, chemical and biological stability and innocuousness [20]. 
$\mathrm{TiO}_{2}$ is only activated by UV radiation, which represents only a small fraction of the solar spectrum. For this reason it is necessary to employ UV lamps, which have high operational costs. Recently, several research groups, in an effort to reduce treatment operational costs, have focused on renewable energy sources, such as natural solar radiation in compound parabolic collectors (CPC) [20], or on more efficient UV lamps, such as UV LEDs [21-23]; and in recent years, the application of UV LEDs lamps has been mainly reported with reference to the discolouration of dyes [24,25], and the degradation of organic compounds [26,27].

The intensity (total number of photons) and the band gap of the photocatalyst have direct influence on the absorbed energy of each photon. Thus, the higher energy of the photons, the higher generation of hydroxyl radicals. An increase in the radiation intensity, will lead to an increase in the degradation rate. However, conventional UV lamps, which are mainly mercury lamps, present several problems. These include overheating because of unstable power consumption, short lifetime, low photonic efficiency, and environmentally unfriendly properties [28]. LEDs are a serious alternative to mercury lamps since they have longer lifetimes, lower energy consumption, and higher efficiency. In addition, they do not overheat and are less harmful to the environment $[28,29]$. Semiconductor LEDs technology is a directional light source with maximum intensity at an angle almost perpendicular to the surface emission. As all emitted photons have approximately the same frequency, the emitted light is monochromatic, and the wavelength depends on the semiconductor material used.

The main objective of this work was to study the efficiency of two different UV-A LED scale-lab photo-systems $(365-370 \mathrm{~nm})$ in the discolouration of an azo dye (Reactive Black 5) in combination with $\mathrm{TiO}_{2}$ and $\mathrm{H}_{2} \mathrm{O}_{2}$, working in a continuous stirred tank reactor (CSTR) and batch mode. Additionally, $\mathrm{TiO}_{2}$ and $\mathrm{TiO}_{2} / \mathrm{H}_{2} \mathrm{O}_{2}$ treatments assisted with solar radiation were carried out in order to compare UV-A LED radiation efficiencies.

\section{Materials and methods}

\subsection{Reagents}

The azo dye, Reactive Black $5\left(\mathrm{C}_{26} \mathrm{H}_{21} \mathrm{~N}_{5} \mathrm{Na}_{4} \mathrm{O}_{19} \mathrm{~S}_{6}\right.$; colour index 20505; $M_{\mathrm{w}}=991.8 \mathrm{~g} / \mathrm{mol}$ ) was provided by DyStar (Portugal) and used as received, without further purification. UV-vis spectra of RB5 consist of two main characteristic absorption bands. One is in the UV region $(310 \mathrm{~nm}$ ) and another in the visible region $(595 \mathrm{~nm})$. The UV band is characterised by two adjacent rings, whereas the visible band is characterised by long conjugated $\pi$ system linked by two azo groups.

$\mathrm{TiO}_{2}$ Degussa P-25, was used as photocatalyst. This photocatalyst contains more than $70 \%$ anatase with a minor amount of rutile and a small amount of amorphous phase [30], with a surface area of $55 \pm 5 \mathrm{~m}^{2} / \mathrm{g}$ and a mean crystallite size of $30 \mathrm{~nm} . \mathrm{TiO}_{2}$ Degussa P-25 was used in concentrations of 0.5 and $1.0 \mathrm{~g} / \mathrm{L}$ [31]. Hydrogen peroxide $\left(\mathrm{H}_{2} \mathrm{O}_{2}\right.$, Panreac, $\left.30 \% \mathrm{w} / \mathrm{v}\right)$ was used alone or in combination with $\mathrm{TiO}_{2}$ in different concentrations (1.76, 4.41, 8.82 and $17.64 \mathrm{mM}$ ). $\mathrm{Na}_{2} \mathrm{SO}_{3}$ (Merck) was used as a reagent grade to quench the hydroxyl radical oxidation.

\subsection{Photoreactor and UV-A LED systems}

All experiments were carried out in continuous and batch mode in a lab-scale prototype reactor and illuminated with two different UV-A LED photo-systems. The reactor had a volume capacity of $110 \mathrm{~mL}$, and the surface was formed of mirrors. Several factors were considered in the construction of the reactor. These included the ideal depth of the solution required to obtain an optimal removal of RB5, the optimal distance between the UV-A LEDs system and the liquid in order to avoid shadow zones, and the obtention of a totally stirred reactor.

The first UV-A LED photo-system was composed of a matrix of 96 Indium Gallium Nitride (InGaN) LEDs lamps (Roithner RLSUV370E), with an illuminated area of $11 \times 7 \mathrm{~cm}^{2}$. These LEDs had a peak light emission at $375 \mathrm{~nm}$, and the nominal consumption of each LED was $80 \mathrm{~mW}$ operating at $20 \mathrm{~mA}$. The total optical power emitted was approximately $100 \mathrm{~mW}$, depending on the root mean square (RMS) current intensity supplied. The system irradiance was measured using a UV enhanced Si-photodetector (ThorLabs PDA155) in a configuration that replicated that used in the photoreactor. In this system, the output optical power was controlled using a pulse width modulation (PWM) circuit and the RMS current intensity was measured with a multimeter (UniVolt DT-64). The experiments were carried out with a RMS current intensity of $240 \mathrm{~mA}$ in the first UV-A LED photo-system, corresponding to an UV irradiance of $23 \mathrm{~W} / \mathrm{m}^{2}$ and a photon flux of $5.53 \times 10^{-7}$ Einstein/s.

In addition, a second, more powerful UV-A LED photo-system was developed with 12 InGaN LEDs lamps (Roithner APG2C1-365E LEDS) with a maximum emission wavelength at $365 \mathrm{~nm}$. The nominal consumption of each LED lamp was $1.4 \mathrm{~W}$ when the applied current was $350 \mathrm{~mA}$. The output optical power was controlled by maintaining the forward current constant using a power MOSFET in six different current settings. In this second photo-system six different current intensities were used. These current intensities ranged from 58 to $326 \mathrm{~mA}$, corresponding to six different UV irradiance values, varying from 16 to $85 \mathrm{~W} / \mathrm{m}^{2}$, and the corresponding photon flux ranging from $3.73 \times 10^{-7}$ to $2.0 \times 10^{-6}$ Einstein/s.

\subsection{Experimental procedure}

Samples were prepared by dissolving $25 \mathrm{mg} / \mathrm{L}$ of RB5 dye in deionised water from a Millipore purification system. Then, the desired amount of $\mathrm{TiO}_{2}(0.5$ or $1.0 \mathrm{~g} / \mathrm{L})$ was added. Further, in order to increase the catalyst dispersion in the dye solution, an ultrasonic bath (Bandelin Sonorex SUPER PK 106) was used. In the experiments carried out in continuous mode, the RB5 solution was pumped to the photoreactor through a peristaltic pump (Gilson Minipuls 3) with a flow rate of $1 \mathrm{~mL} / \mathrm{min}$.

In the $\mathrm{TiO}_{2} / \mathrm{H}_{2} \mathrm{O}_{2}$ and $\mathrm{H}_{2} \mathrm{O}_{2} / \mathrm{UV}$ experiments different concentrations of $\mathrm{H}_{2} \mathrm{O}_{2}$ were tested (1.76, 4.41, 8.82 and $\left.17.64 \mathrm{mM}\right)$. The $\mathrm{H}_{2} \mathrm{O}_{2}$ was directly added to the photoreactor at the beginning of each experiment. Samples of the dye solution were withdrawn at periodic intervals during the course of the reaction, and analysed using a Jasco V-530 UV/VIS (Tokyo, Japan) double-beam spectrophotometer. The colour of the dye solution in the reaction mixture at different times, was obtained by measuring the absorbance at maximum wavelength $\left(\lambda_{\max }=595 \mathrm{~nm}\right)$ and by computing the concentration from the calibration curve. The $\mathrm{H}_{2} \mathrm{O}_{2}$ concentration was monitored via Merckoquant peroxide analytical test strips (Test Peroxides, Merck Merckoquant). The temperature and $\mathrm{pH}$ of the samples was monitored using a $209 \mathrm{pH}$ Meter from Hanna Instruments. The temperature remained constant around $21^{\circ} \mathrm{C}$, while $\mathrm{pH}$ decreased from 5 to 4.5 during the treatment.

Solar photocatalytic experiments were carried out on the roof of the Geociências building at Universidade de Trás-os-Montes e Alto Douro (41 ${ }^{\circ} 17^{\prime} 10.7^{\prime \prime} \mathrm{N} ; 7^{\circ} 44^{\prime} 21.1^{\prime \prime} \mathrm{W}$ ) in Vila Real (Portugal) during the month of July 2014. The average annual value of global solar irradiance in Vila Real (Portugal) is between 4000 and $4500 \mathrm{Wh} / \mathrm{m}^{2}$ per day. Fig. S1 (Supplementary material) shows the two UV-A LED photosystem and a diagram of the setup of the solar photocatalytic experiment in continuous mode. 
All the experiments were carried out in duplicate and values presented are the average of both results. The observed standard deviation was always less than $5 \%$ of the reported value.

In addition, some adsorption tests were carried out in a previous phase of the research. Nevertheless, the adsorbed amount of RB5 in the photocatalyst was considered negligible.

\subsection{Statistical analysis}

A statistical analysis of the experimental results was performed with Minitab 17 Statistical Software in order to evaluate the influence of the different variables involved in the treatments performed on a response factor (percentage of RB5 discolouration). To do this, a two-level factorial design $\left(2^{\mathrm{k}}\right)$ was selected, and the variables considered were $\mathrm{TiO}_{2}$ concentration $(0.5$ and $1 \mathrm{~g} / \mathrm{L}), \mathrm{H}_{2} \mathrm{O}_{2}$ concentration (1.76 and $17.64 \mathrm{mM}$ ), type of radiation (UV-A LED and solar radiation) and reaction mode (continuous and batch mode).

\subsection{Electrical energy determination}

One of the most important disadvantages of photocatalytic treatments is the high operational cost mainly associated with the electrical energy required by UV radiation. Bolton et al. defined the figures-of-merit electric energy per order $\left(E_{\mathrm{EO}}\right)$ to use in the firstorder kinetic regime of AOPs when the low pollutant concentrations (which apply here) are solved in solution [32].

The above parameter refers to the electric energy in kilowatt hours $(\mathrm{kWh})$ required to reduce the concentration of a pollutant $\mathrm{C}$ by one order of magnitude in a unit volume $(1000 \mathrm{~L})$ of contaminated water. $E_{\mathrm{EO}}$ can be calculated as follows (Eqs. (1) and (2)):

$E_{\mathrm{EO}}=\frac{P \times t \times 1000}{V \times \log \left(\frac{c_{\mathrm{i}}}{c_{\mathrm{f}}}\right)}$ Batchmode

$E_{\mathrm{EO}}=\frac{P}{F \times \log \left(\frac{C_{\mathrm{i}}}{C_{\mathrm{f}}}\right)}$ Continuousflowmode

where $P$ is the rated power $(\mathrm{kW})$ of the system, $V$ is the volume (L) of water treated in the time $t(\mathrm{~h}), F$ is the water volume flow rate $\left(\mathrm{m}^{3} / \mathrm{h}\right), C_{\mathrm{i}}$ and $C_{\mathrm{f}}$ are the initial and final concentrations $(\mathrm{mol} / \mathrm{L})$ and the factor of 1000 converts $g$ to $\mathrm{kg}$. Higher $E_{\mathrm{EO}}$ values correspond to lower removal efficiencies.

\section{Results and discussion}

\subsection{Batch experiments}

Fig. 1 shows the RB5 discolouration after the photocatalytic treatment with 0.5 and $1 \mathrm{~g} / \mathrm{L}$ of $\mathrm{TiO}_{2}$ with UV-A LEDs and solar radiation. As can be seen, the treatments carried out in the presence of solar radiation produced better results than those performed with the UV-A LED radiation. After $10 \mathrm{~min}$ of photocatalytic oxidation with solar radiation, $90-95 \%$ of RB5 was discoloured, while, a higher time was required when UV-A LED radiation was used-specifically $60 \mathrm{~min}$ with $1 \mathrm{~g} / \mathrm{L}$ of $\mathrm{TiO}_{2}$, and $120 \mathrm{~min}$ with $0.5 \mathrm{~g} / \mathrm{L}$. This large difference is due to the different irradiance exposure of the effluent with the solar radiation and UVA LEDs.

In addition, the influence of $\mathrm{TiO}_{2}$ dosage in the final yield of the treatment can also be observed. When photocatalysis was carried out in the presence of UV-A LED radiation, a higher dosage of $\mathrm{TiO}_{2}$ was required to obtain a faster discolouration of RB5. However, the

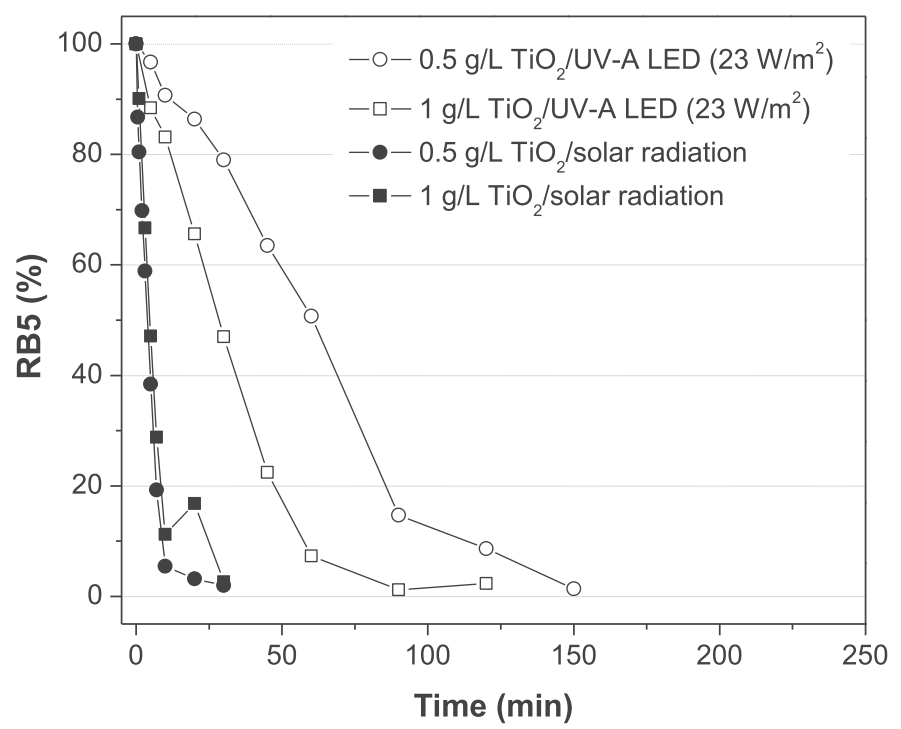

Fig. 1. RB5 discolouration through photocatalysis $\left(0.5\right.$ and $1.0 \mathrm{~g} / \mathrm{L}$ of $\left.\mathrm{TiO}_{2}\right)$ in batch mode with UV-A LED radiation (open symbols) and solar radiation (closed symbols).

same relationship was not observed in the treatments performed with solar radiation. In this case, a higher dosage of catalyst slightly slowed the discolouration rate of the dye.

Table $1 \mathrm{~A}$ shows that in almost all of the experiments, the discolouration of dye during the first 30 min of oxidation could be described as a first order reaction kinetics regarding to dye concentration. Table 1 also shows the values of electric energy per order $\left(E_{\mathrm{EO}}\right)$ for those treatments performed with UV-A LED radiation.

Initial discolouration rate constants were determined from the slope of $\ln \left(C_{0} / C\right)$ vs $t(\mathrm{~min})$ plots, where $C_{0}$ and $C$ are the dye concentration at zero and $t$ time, respectively. The constant rate $(k)$ of UV-A LED photocatalysis increases two fold when the amount of $\mathrm{TiO}_{2}$ is doubled $\left(0.010\right.$ and $0.0188 \mathrm{~min}^{-1}$ with 0.5 and $1 \mathrm{~g} / \mathrm{L} \mathrm{TiO}_{2}$, respectively). As mentioned above, the solar photocatalysis experiments were considerably faster than those carried out with UV-A LED radiation. However, when sunlight was used as a radiation source, a higher dosage of $\mathrm{TiO}_{2}$ caused a drop in the rate constant $\left(0.3086\right.$ and $0.2340 \mathrm{~min}^{-1}$ with 0.5 and $1 \mathrm{~g} / \mathrm{L} \mathrm{TiO}_{2}$ respectively). The time necessary to reduce the initial concentration of RB5 to $50 \%$, and the half-life time $\left(t_{1 / 2}\right)$ are presented as further details of the discolouration process.

In order to increase the yield and rate of dye discolouration, different dosages of hydrogen peroxide (1.76, 4.41, 8.82 and $17.64 \mathrm{mM}$ ) were added to the photocatalytic treatments with UV-A LED (Fig. 2A) and solar radiation (Fig. 2B). As can be seen in both figures, the addition of hydrogen peroxide allowed an increase in the discoloration rate of RB5 dye.

As seen in Table $1 \mathrm{~A}$, when $0.5 \mathrm{~g} / \mathrm{L}$ of $\mathrm{TiO}_{2}$ was added, the fastest molar ratio $\mathrm{TiO}_{2}: \mathrm{H}_{2} \mathrm{O}_{2}$ was $3.55\left(0.5 \mathrm{~g} / \mathrm{L}\right.$ of $\left.\mathrm{TiO}_{2}: 1.764 \mathrm{mM} \mathrm{H}_{2} \mathrm{O}_{2}\right)$, with a rate constant of $0.0447 \mathrm{~min}^{-1}-4.5$ times faster than the photocatalysis treatment with $0.5 \mathrm{~g} / \mathrm{L}$ of $\mathrm{TiO}_{2}$ in the absence of $\mathrm{H}_{2} \mathrm{O}_{2}$. The rate constant of the RB5 discolouration decreased with increased of $\mathrm{H}_{2} \mathrm{O}_{2}$ concentration. The optimal ratio varied when $1 \mathrm{~g} / \mathrm{L}$ of $\mathrm{TiO}_{2}$ was added. In this case, the same concentration of hydrogen peroxide was required to achieve the fastest yield: molar ratio $\mathrm{TiO}_{2}: \mathrm{H}_{2} \mathrm{O}_{2}\left(1 \mathrm{~g} / \mathrm{L}\right.$ of $\left.\mathrm{TiO}_{2}: 1.764 \mathrm{mM} \mathrm{H}_{2} \mathrm{O}_{2}\right) 7.09$, with a rate constant of $0.0728 \mathrm{~min}^{-1}$. Lower ratios $\left(\mathrm{TiO}_{2}: \mathrm{H}_{2} \mathrm{O}_{2}\right)$ were required in those treatments carried out in the presence of solar radiation due to the strong influence of radiation in the treatment. Finally, different blank experiments were carried out in order to verify the influence of the variables independently (data not shown). In the 
Table 1

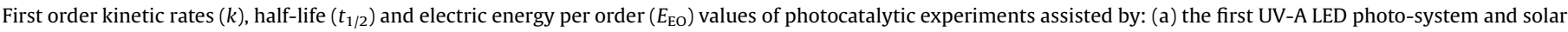
radiation in batch continuous flow mode; (b) the second UV-A LED photo-system in batch mode.

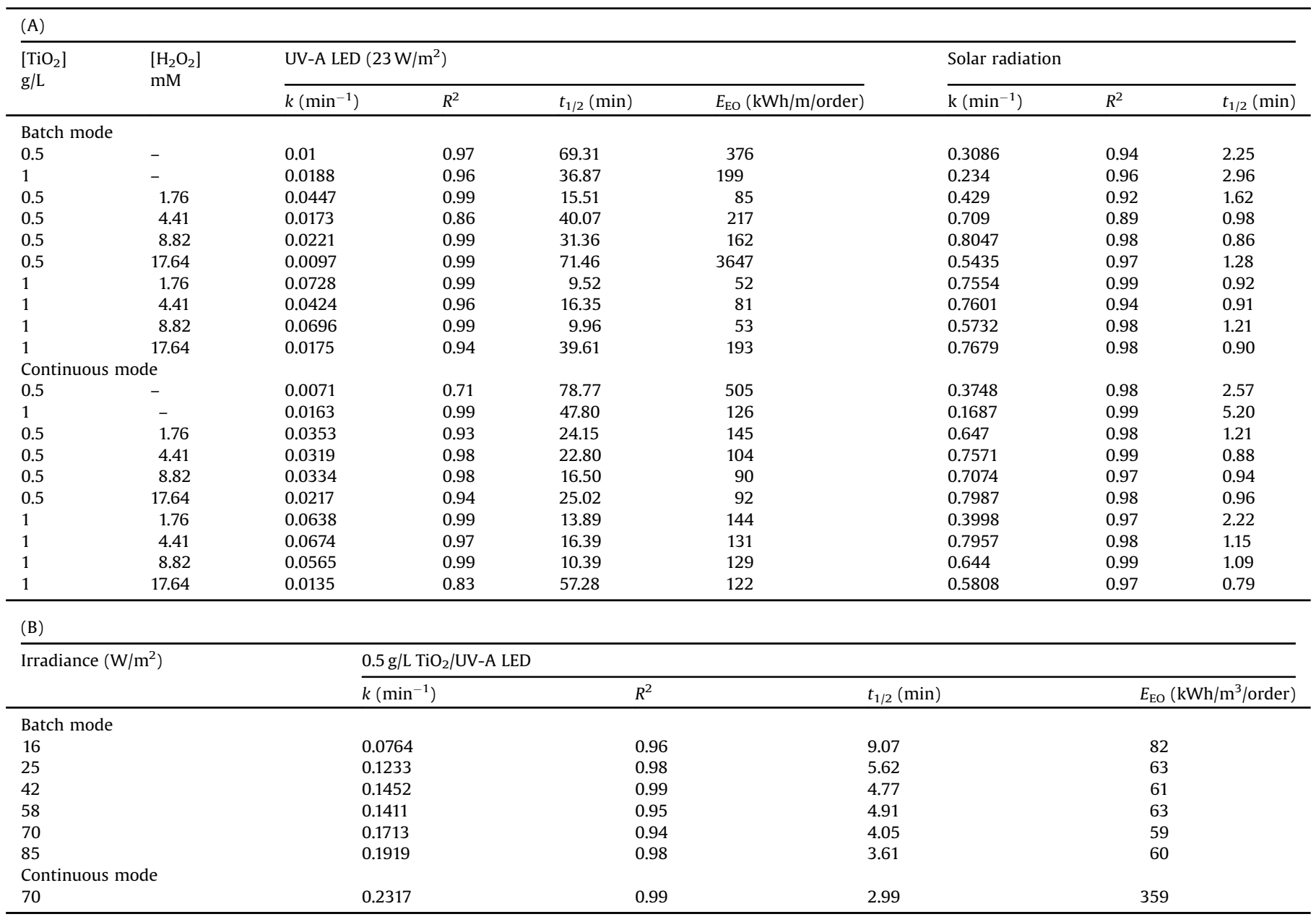

$\mathrm{H}_{2} \mathrm{O}_{2}$ /UV-A LED treatments, radiation did not have any influence over the RB5 dye. Similar conclusions were reached when the effluent was exposed to UV-A LED radiation in absence of other chemicals such as $\mathrm{TiO}_{2}$ or $\mathrm{H}_{2} \mathrm{O}_{2}$.

On the other hand, and as shown in Table $1 \mathrm{~A}$, with increasing $\mathrm{TiO}_{2}$ concentration the value of $E_{\mathrm{EO}}$ decreases, and so the efficiency of the $\mathrm{TiO}_{2} / \mathrm{UV}$-A LEDs treatment improves. In contrast, because the $E_{\mathrm{EO}}$ value increases with increasing $\mathrm{H}_{2} \mathrm{O}_{2}$ concentration in those treatments combining $\mathrm{TiO}_{2}$ and $\mathrm{H}_{2} \mathrm{O}_{2}$, efficiency improves considerably with lowering concentrations of hydrogen peroxide. These results confirm those observed in the kinetic rates of RB5 discolouration.

\subsection{Continuous experiments}

Fig. 3 shows the RB5 discolouration after the photocatalytic treatments with 0.5 and $1 \mathrm{~g} / \mathrm{L}$ of $\mathrm{TiO}_{2}$ with UV-A LEDs and solar radiation, using a flow rate of $1 \mathrm{~mL} / \mathrm{min}$. Again, the treatments carried out in the presence of solar radiation produced better results than those performed with UV-A LED radiation. As can be observed in Fig. 3, all the treatments achieved total discolouration of the aqueous solution, except the treatment with $0.5 \mathrm{~g} / \mathrm{L}$ of $\mathrm{TiO}_{2}$ irradiated with UV-A LED. This reached a steady state after $270 \mathrm{~min}$ at $63 \%$ of discolouration.

Kinetic modelling was approached via a first order model, taking into account the fact that the retention time of effluent in the reactor is almost the same as the reaction time in the batch reactor. In this way, batch and continuous mode experiments could be compared.

Regarding the rate constant observed in Table $1 \mathrm{~A}$, the faster treatment carried out with $0.5 \mathrm{~g} / \mathrm{L}$ of $\mathrm{TiO}_{2}$ and solar radiation $\left(0.3748 \mathrm{~min}^{-1}\right)$ was 53 times faster than the same treatment assisted with UV-A LED radiation. The increase of $\mathrm{TiO}_{2}$ concentration to $1 \mathrm{~g} / \mathrm{L}$ should have increased the RB5 discolouration rate, but this increase was only observed in the presence of UV-A LED radiation. In addition, the experiment using $1 \mathrm{~g} / \mathrm{L} \mathrm{TiO}_{2}$ with solar radiation achieved a rate constant of $0.1687 \mathrm{~min}^{-1}$-two times lower than the same treatment with half of theTiO $\mathrm{T}_{2}$ concentration. This effect could be a consequence of the presence of shadow zones due to a high concentration of $\mathrm{TiO}_{2}$.

The rate constant values obtained in continuous mode were expected to be slower than those of the treatments carried out in batch mode, due to the introduction of new effluent with a flow rate of $1 \mathrm{~mL} / \mathrm{min}$. However, comparing rates constants shown in Table $1 \mathrm{~A}$ and $\mathrm{B}$, this difference was not observed in those treatments carried out with $0.5 \mathrm{~g} / \mathrm{L}$ of $\mathrm{TiO}_{2}$, which were slightly faster in continuous mode.

Fig. $4 \mathrm{~A}$ shows the degradation results of RB5 after the $\mathrm{TiO}_{2} / \mathrm{H}_{2} \mathrm{O}_{2}$ assisted with UV-A LED radiation treatments with 0.5 and $1 \mathrm{~g} / \mathrm{L}$ of $\mathrm{TiO}_{2}$ in continuous mode. As shown in this figure, the discolouration rate of RB5 increases with higher $\mathrm{H}_{2} \mathrm{O}_{2}$ dosage and $0.5 \mathrm{~g} / \mathrm{L}$ of $\mathrm{TiO}_{2}$. However, some authors have reported that an excessive 
A)
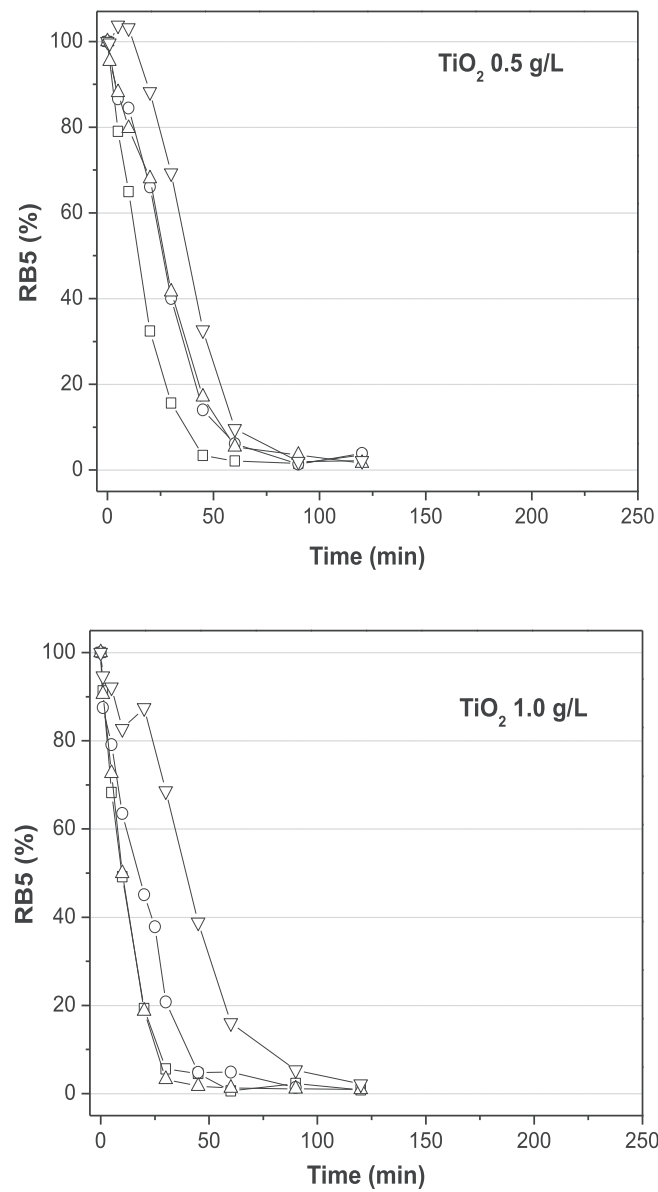

B)
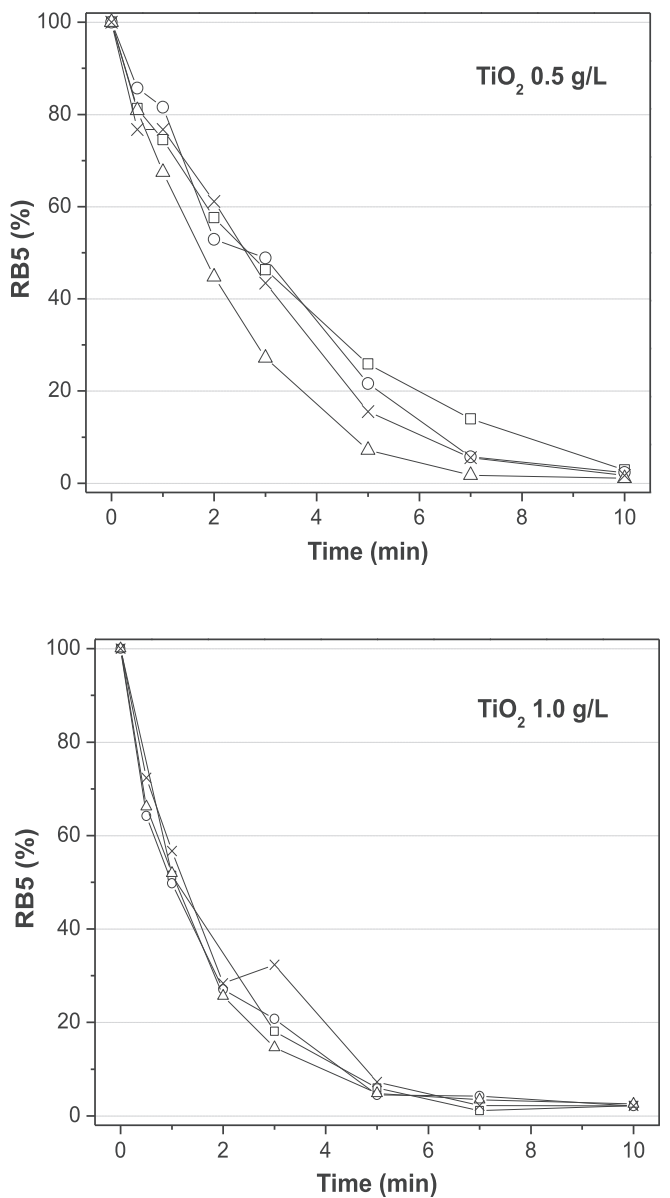

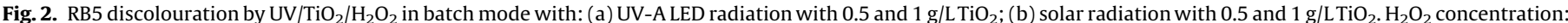
( $\square$ ) $1.76 \mathrm{mM}$; $\bigcirc) 4.41 \mathrm{mM}$; $(\triangle) 8.82 \mathrm{mM}$; $(\nabla) 17.64 \mathrm{mM}$.

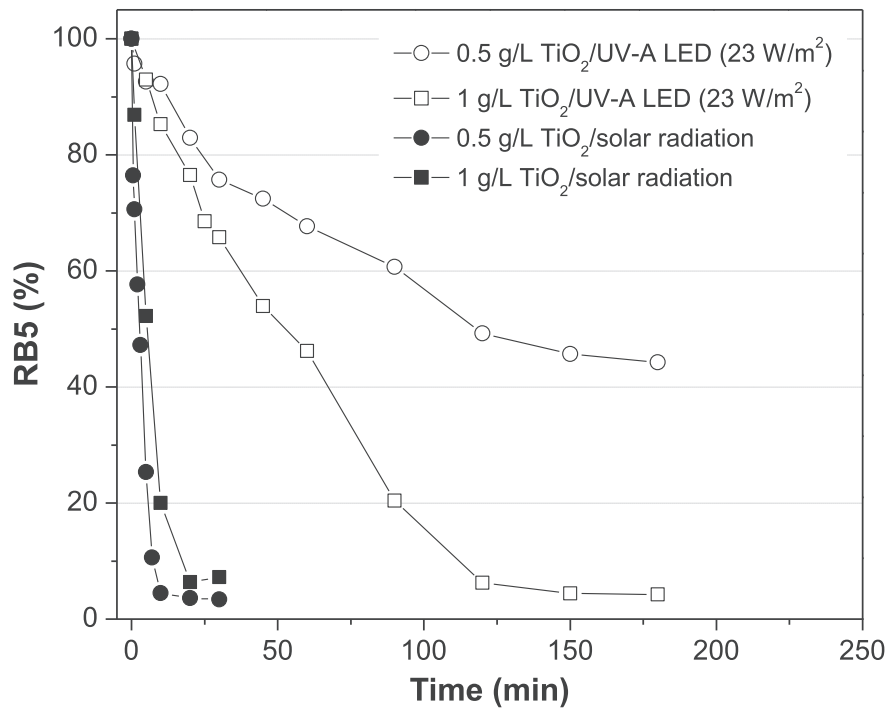

Fig. 3. RB5 discolouration by photocatalysis $\left(0.5\right.$ and $1 \mathrm{~g} / \mathrm{L}$ of $\left.\mathrm{TiO}_{2}\right)$ in continuous mode with UV-A LED radiation (open symbols) and solar radiation (closed symbols).

dosage of $\mathrm{H}_{2} \mathrm{O}_{2}$ can generate a contrary effect due to the occurrence of scavenger reactions [33] and the highest used dosage of hydrogen peroxide did not produce the optimum discolouration of RB5. The highest constant rate of discolouration for treatments with $0.5 \mathrm{~g} / \mathrm{L}$ of $\mathrm{TiO}_{2}$ was $0.0334 \mathrm{~min}^{-1}$. This was achieved with $0.5 \mathrm{~g} / \mathrm{L} \mathrm{TiO}_{2} / 8.82 \mathrm{mM} \mathrm{H}_{2} \mathrm{O}_{2}$. However, the highest dosage of hydrogen peroxide $\left(17.64 \mathrm{mM} \mathrm{H}_{2} \mathrm{O}_{2}\right.$ ) decreased the rate constant of discolouration to $0.0217 \mathrm{~min}^{-1}$. Values of constant rates can be observed in Table $1 \mathrm{~A}$.

With $1 \mathrm{~g} / \mathrm{L}$ of $\mathrm{TiO}_{2}$ and different dosages of $\mathrm{H}_{2} \mathrm{O}_{2}$, the highest concentration of $\mathrm{H}_{2} \mathrm{O}_{2}(17.64 \mathrm{mM})$ decreased the rate of dye discolouration. This treatment rate, $\left(1 \mathrm{~g} / \mathrm{L} \mathrm{TiO}_{2} / 17.64 \mathrm{mM} \mathrm{H}_{2} \mathrm{O}_{2}\right.$; $0.0135 \mathrm{~min}^{-1}$ ), is lower than that obtained with a combination of a lower concentration of $\mathrm{TiO}_{2} \quad\left(0.5 \mathrm{~g} / \mathrm{L} \quad \mathrm{TiO}_{2} / 17.64 \mathrm{mM} \quad \mathrm{H}_{2} \mathrm{O}_{2}\right.$; $0.0217 \mathrm{~min}^{-1}$ ), and it is even lower than the photocatalytic treatment without hydrogen peroxide $\left(1 \mathrm{~g} / \mathrm{L} \mathrm{TiO}_{2} ; 0.0163 \mathrm{~min}^{-1}\right)$.

Fig. 4B shows the degradation results of RB5 after the $\mathrm{TiO}_{2} / \mathrm{H}_{2} \mathrm{O}_{2}$ assisted with solar radiation treatments with 0.5 and $1 \mathrm{~g} / \mathrm{L}$ of $\mathrm{TiO}_{2}$ in continuous mode. This figure shows clearly that the combination of $0.5 \mathrm{~g} / \mathrm{L}$ of $\mathrm{TiO}_{2}$ with $8.82 \mathrm{mM}$ of $\mathrm{H}_{2} \mathrm{O}_{2}$ was (again) the fastest of the studied treatments. $87 \%$ of RB5 was discoloured after 2 min of treatment using $8.82 \mathrm{mM}$ of $\mathrm{H}_{2} \mathrm{O}_{2}$, while only $54 \%$ of dye was discoloured when $17.64 \mathrm{mM}$ of $\mathrm{H}_{2} \mathrm{O}_{2}$ was combined with $0.5 \mathrm{~g} / \mathrm{L}$ of $\mathrm{TiO}_{2}$. In all cases, total discolouration of dye was achieved after 10 min of treatment. These results can be cross-checked with rate constants presented in Table $1 \mathrm{~A}$. However, small differences between the four treatments studied were observed. Taking into account the rate constants, the fastest treatment was the combination of $17.64 \mathrm{mM} \mathrm{H}_{2} \mathrm{O}_{2}$ with $0.5 \mathrm{~g} / \mathrm{L} \mathrm{TiO}_{2}\left(0.7987 \mathrm{~min}^{-1}\right)$. In the case of $1 \mathrm{~g} / \mathrm{L}$ of $\mathrm{TiO}_{2}$, the highest rate of discolouration of aqueous solution of dye was achieved with a dosage of $4.41 \mathrm{mM}$ of 
A)
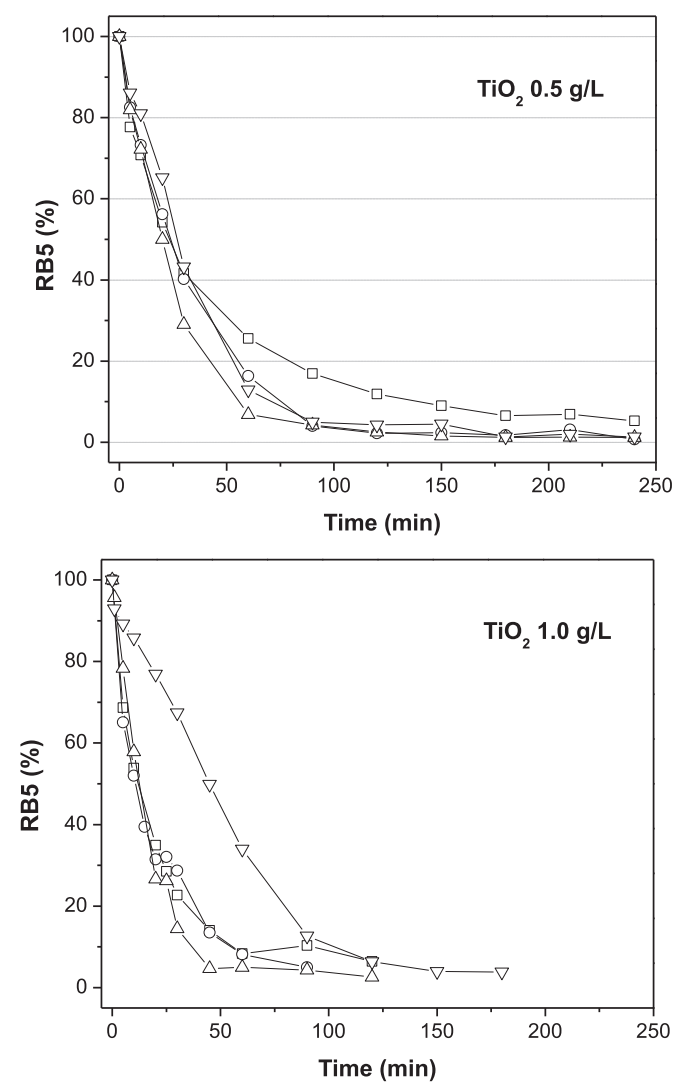

B)
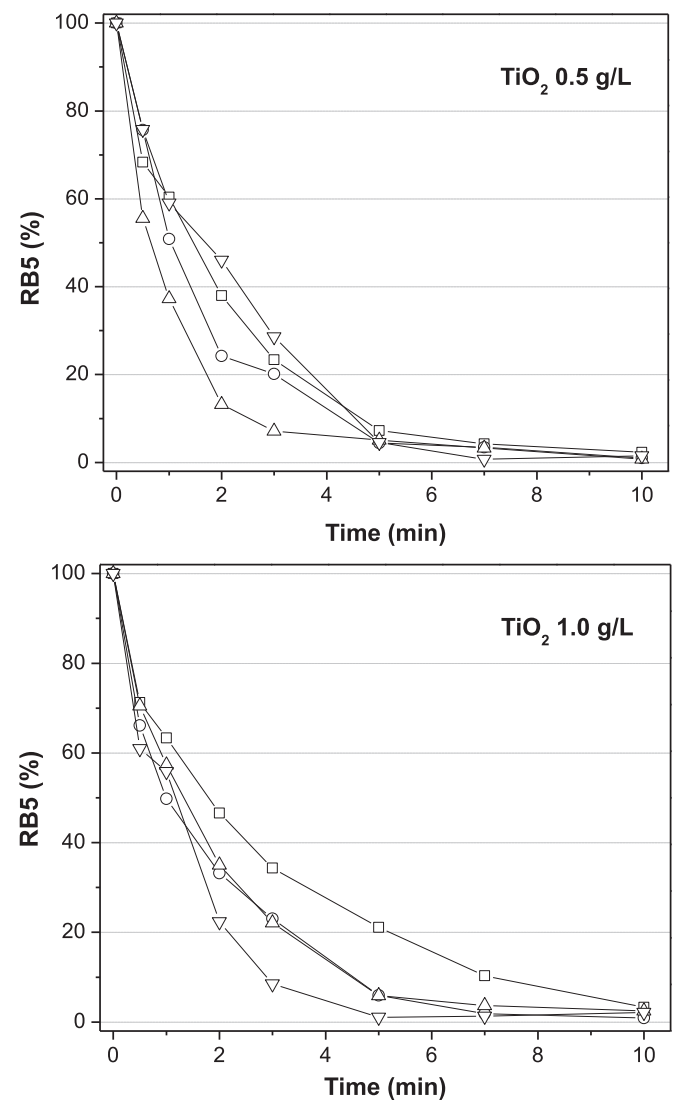

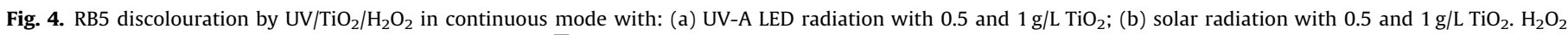
concentration: $(\square) 1.76 \mathrm{mM}$; $(\bigcirc) 4.41 \mathrm{mM} ;(\triangle) 8.82 \mathrm{mM}$; $(\nabla) 17.64 \mathrm{mM}$.

$\mathrm{H}_{2} \mathrm{O}_{2}\left(0.7957 \mathrm{~min}^{-1}\right)$. All rate constants, except that of the treatment $1 \mathrm{~g} / \mathrm{L} \mathrm{TiO}_{2} / 4.41 \mathrm{mM} \mathrm{H}_{2} \mathrm{O}_{2}\left(0.7957 \mathrm{~min}^{-1}\right)$ were lower than those reached with a combination of $0.5 \mathrm{~g} / \mathrm{L}$ of $\mathrm{TiO}_{2}$ and hydrogen peroxide (Table $1 \mathrm{~A}$ ). These results obtained with solar radiation are around 10-25 times faster than those observed with UV-A LED radiation. Table $1 \mathrm{~A}$ also shows the $E_{\mathrm{EO}}$ values of treatments in continuous mode. In this reaction mode, the efficiency behaviour of the treatments is totally different from treatments in batch mode. Without $\mathrm{H}_{2} \mathrm{O}_{2}$, the efficiency of the treatments increases with the increase of concentration of $\mathrm{TiO}_{2}$. On the other hand, with $\mathrm{H}_{2} \mathrm{O}_{2}$, the highest efficiency was observed with the lowest concentration of $\mathrm{TiO}_{2}(0.5 \mathrm{~g} / \mathrm{L})$ combined with increasing concentrations of $\mathrm{H}_{2} \mathrm{O}_{2}$, reaching a peak with a concentration of $8.82 \mathrm{mM}$.

\subsection{Statistical analysis}

The results obtained were statistically analysed in order to assess the influence of each variable in the treatment. Thus, the effect of the following variables on the discolouration results obtained after $5 \mathrm{~min}$ of contact time were studied: $\mathrm{TiO}_{2}$ concentration ( 0.5 and $1 \mathrm{~g} / \mathrm{L}), \mathrm{H}_{2} \mathrm{O}_{2}$ concentration (1.76 and $17.64 \mathrm{mM}$ ), type of radiation (UV-A LED and solar radiation) and reaction mode (continuous and batch mode). Fig. $5 \mathrm{~A}$ and $\mathrm{B}$ portrays the main effects plot and the interaction plot respectively. The main effects plot in Fig. 5A represents the effect of each variable on the response factor. This type of representation shows the contribution to the response factor of changing one of the influential variables chosen for photocatalytic treatments. As can be observed in the figure, the variable with the highest influence on the treatment is the radiation type, -with solar radiation mainly reaching the higher discolouration yields. As to the rest of variables, the increase of $\mathrm{TiO}_{2}$ has a slight positive effect on the discolouration of RB5, while the opposite effect is seen with the increase of $\mathrm{H}_{2} \mathrm{O}_{2}$ concentration. Finally, as shown in the figure, the discolouration results improve slightly in continuous mode compared to batch mode. The results on the response factor (RB5 discolouration) of different interactions among the different variables can be seen in the interaction plot.

\subsection{Development of more powerful UV-A LED photo system}

Although the first UV-A LED photo-system achieved promising results, it was not considered sufficient to obtain similar results to those obtained with solar photocatalysis. For this reason, a new and more powerful UV-A LED photo-system was developed. Fig. 6 shows the results after the application of $0.5 \mathrm{~g} / \mathrm{L}$ of $\mathrm{TiO}_{2}$ with different irradiance dosages $\left(16-85 \mathrm{~W} / \mathrm{m}^{2}\right)$ in batch mode. As can be observed in this figure, the rate of dye discolouration increased with increasing irradiance.

Table 1B shows the kinetic parameters obtained after the application of the second UV-A LED photo-system. As shown above, the constant rate increases progressively with increasing irradiance. Thus, photocatalysis assisted with $85 \mathrm{~W} / \mathrm{m}^{2}$ had a rate discolouration of $0.1919 \mathrm{~min}^{-1}$. A comparison of these kinetic values with those produced by the first UV-A LED photo-system and solar radiation (Table $1 \mathrm{~A}$ and $\mathrm{B}$ ), reveals the high efficiency of the second photo-system. All irradiances tested in the second photo-system (from 0.0764 to $0.1919 \mathrm{~min}^{-1}$ ) exceed the rate discolouration obtained with the first system $\left(0.010 \mathrm{~min}^{-1}\right)$. With 
A)
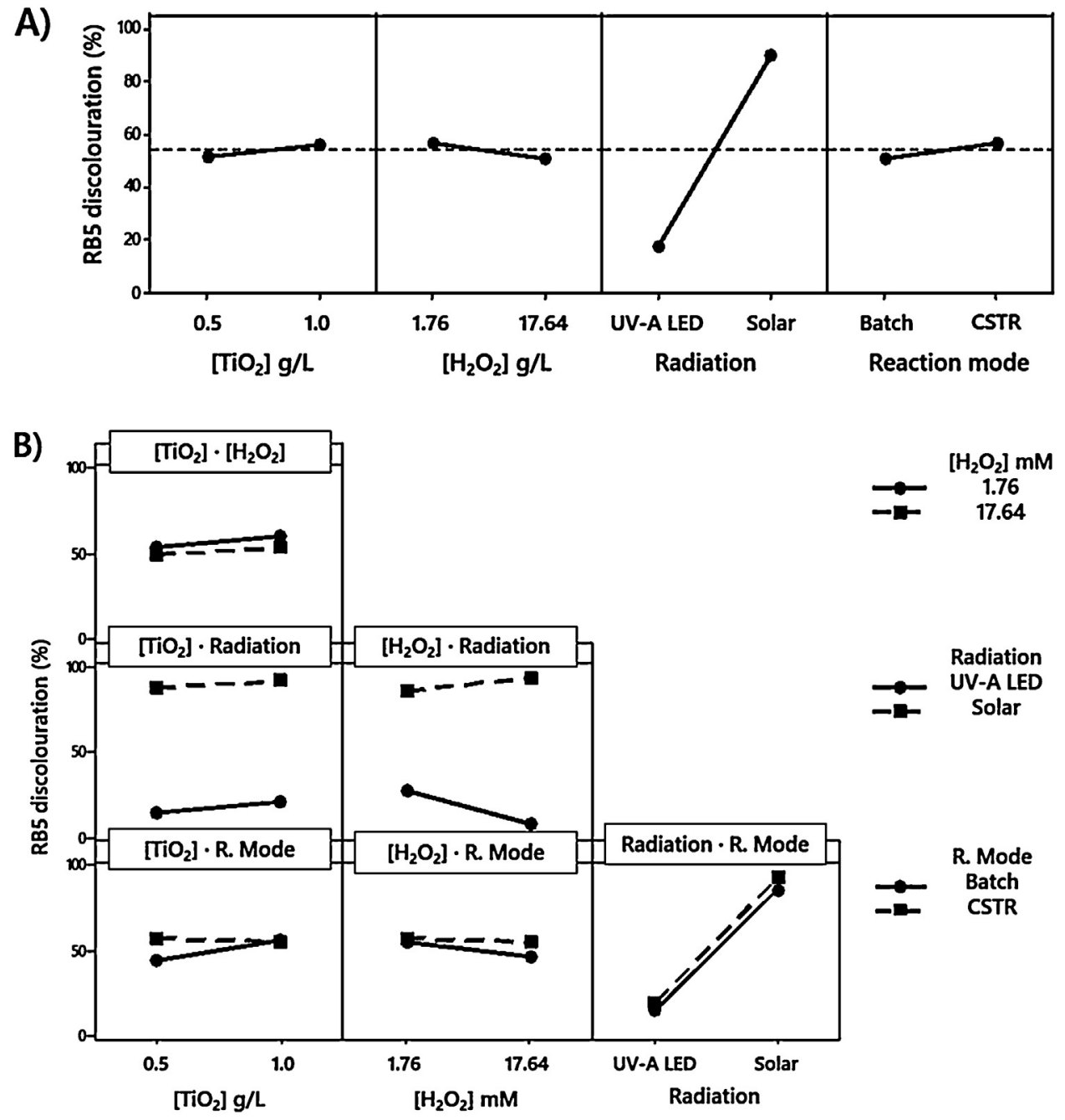

Fig. 5. Statistical analysis of variables: (a) main effects plot; (b) interaction plot.

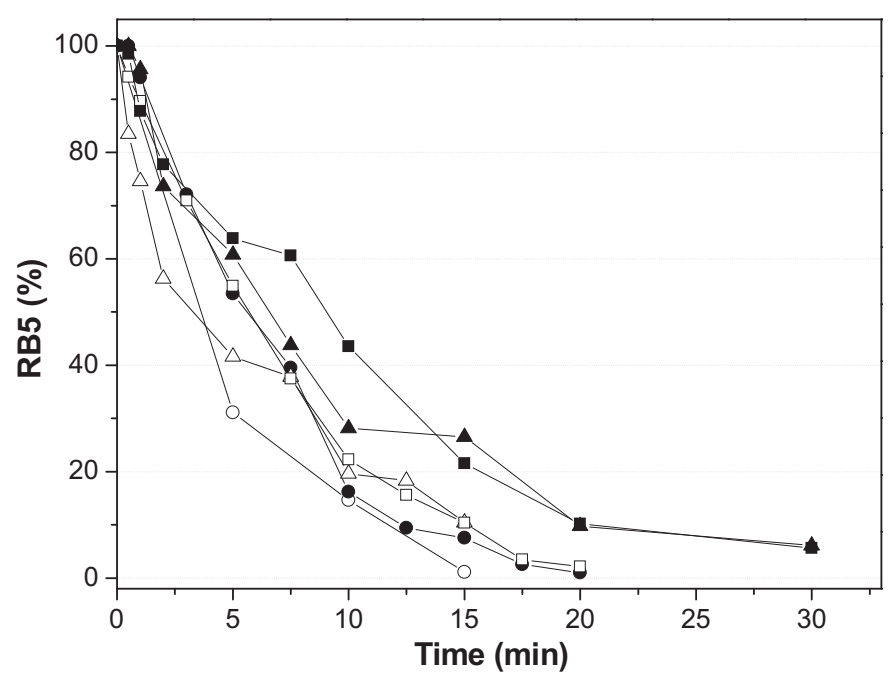

Fig. 6. RB5 discolouration by photocatalysis with $0.5 \mathrm{~g} / \mathrm{L}$ of $\mathrm{TiO}_{2}$ assisted with the second UV-A LED photosystem. UV irradiance $\left(\mathrm{W} / \mathrm{m}^{2}\right)$ : ( $\left.\boldsymbol{\square}\right) 16 ;(\boldsymbol{\Delta}) 25 ;(\square) 42 ;(\triangle)$ 58; (○) 70 and $(\bigcirc) 85$. respect to solar radiation $\left(0.3086 \mathrm{~min}^{-1}\right)$, UV-A LED radiation was already slower; however slight differences were observed between both treatments. In addition, a comparison of the two photosystems was carried out in continuous mode. Fig. 7 shows the comparison of continuous experiments carried out with $0.5 \mathrm{~g} / \mathrm{L}$ of $\mathrm{TiO}_{2}$ with a flow rate of $1 \mathrm{~mL} / \mathrm{min}$ and 23 and $70 \mathrm{~W} / \mathrm{m}^{2}$ of irradiance in the first and second photo-system respectively. It is clearly shown, that the second UV-A LED photo-system achieved the total discolouration of the dye in only $20 \mathrm{~min}$, while a maximum discolouration of $63 \%$ was attained in the first UV-A LED photosystem after $270 \mathrm{~min}$ of treatment, at which time, it reached a steady state.

\subsection{Comparison of processes}

As observed in the results, the first UV-A LED photo-system was not able to achieve the same yield as solar radiation. Therefore, a more powerful and efficient photo-system was developed. A comparison of $E_{\mathrm{EO}}$ values in those treatments performed in both photo-systems (Table 1 ) shows that the highest $E_{\mathrm{EO}}$ value was obtained with the first UV-A LED photo-system $\left(3647 \mathrm{kWh} / \mathrm{m}^{3}\right.$ / order). Nevertheless, the $E_{\mathrm{EO}}$ values of second UV-A LED system were between 4 and 6 times lower than the first photo-system. These results confirm the low efficiency of the first photo-system, 


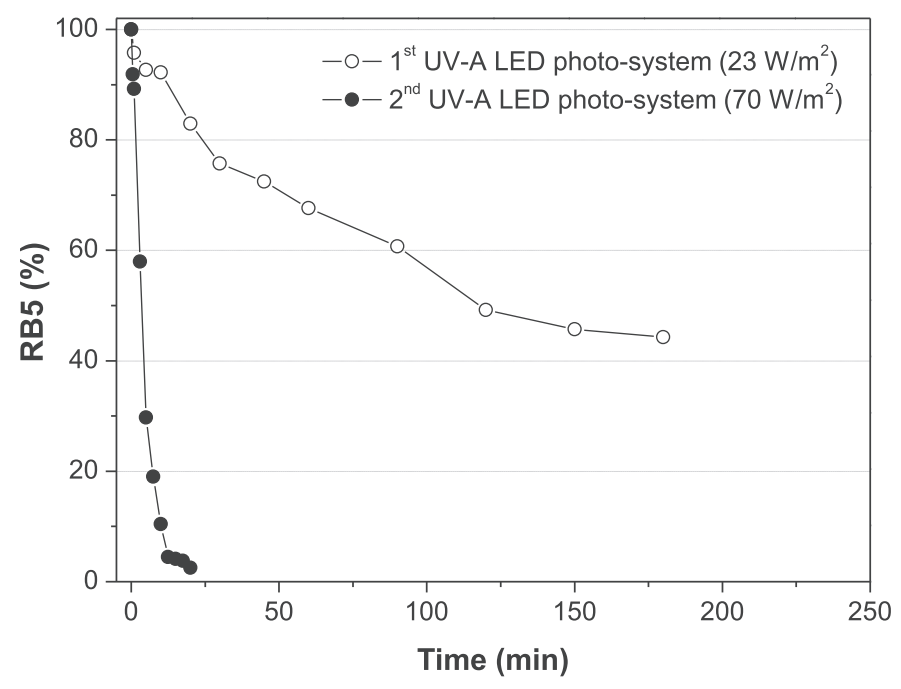

Fig. 7. Comparison of UV-A LED photosystems in the photocatalytic discolouration of RB5 in continuous mode: $0.5 \mathrm{~g} / \mathrm{L} \mathrm{TiO}_{2} ; 25 \mathrm{mg} / \mathrm{L} \mathrm{RB} 5 ; F=1 \mathrm{~mL} / \mathrm{min}$.

and show the second system to be much more adequate to perform photocatalytic treatments. Moreover, it was observed that the efficiency of the treatment $\left(E_{\mathrm{EO}}\right)$ increases slightly with the irradiance. The highest efficiency was observed using $70 \mathrm{~W} / \mathrm{m}^{2}$ of irradiance $\left(59 \mathrm{kWh} / \mathrm{m}^{3} /\right.$ order). These $E_{\mathrm{EO}}$ values were compared with those obtained under the same operational conditions $(0.5 \mathrm{~g} / \mathrm{L}$ $\mathrm{TiO}_{2}$ ) but using a medium pressure mercury lamp (Heraeus TQ150). Using the mercury lamp, $20 \%$ of RB5 disappeared after 10 min and taking into account Eq. (1), a value of $877 \mathrm{kWh} / \mathrm{m}^{3} /$ order was obtained, which demonstrates a lower efficiency than UV-A LED lamps. In addition, the efficiency values of the second UV-A LED photo-system are higher than those reported by other authors in the degradation of different dyes through $\mathrm{TiO}_{2} / \mathrm{UV}$ with conventional lamps. These indicate expected higher values of $E_{\mathrm{EO}}$, due to the high electrical cost $(0.150 \mathrm{~kW})$ and the slow discolouration of RB5 For instance, Khataee et al., achieved efficiency values in the 71-98 $\mathrm{kWh} / \mathrm{m}^{3}$ /order in the discolouration of three different dyes (Acid Orange 8, 10 and 12) using $4 \mathrm{~g} / \mathrm{L}$ of $\mathrm{TiO}_{2} / \mathrm{UV}-\mathrm{A}$ radiation (365 nm; 15-W UV lamp) [34] and Yu et al., reported the discolouration of $20 \mathrm{mg} / \mathrm{L}$ of $\mathrm{RB} 5$ by $1 \mathrm{~g} / \mathrm{L} \mathrm{TiO} / 2 / \mathrm{UV}-\mathrm{C}$ radiation (15-W UVC lamp; $254 \mathrm{~nm} ; 10 \mathrm{~mW} / \mathrm{cm}^{2}$ ) after $100 \mathrm{~min}$ [35].

Finally, the efficiency of both photo-systems was compared in continuous mode using the most efficient irradiance of the second system $\left(70 \mathrm{~W} / \mathrm{m}^{2}\right)$ in the treatment with $0.5 \mathrm{~g} / \mathrm{L}$ of $\mathrm{TiO}_{2}$. Again, the $E_{\mathrm{EO}}$ values indicate that higher efficiency is produced through the use of the second UV-A LED photo-system $\left(359 \mathrm{kWh} / \mathrm{m}^{3} /\right.$ order $)$ compared to the first photo-system $\left(505 \mathrm{kWh} / \mathrm{m}^{3} /\right.$ order $)$. However, Natarajan et al., reported the discolouration of several dyes (Malachite Green, Methylene Blue and Rhodamine B) in a concentration of $5 \mathrm{mg} / \mathrm{L}$ through $\mathrm{TiO}_{2} / \mathrm{UV}-\mathrm{A}$ LED treatments in continuous mode [28]. The $E_{\mathrm{EO}}$ values reported by Natarajan et al., are in the $780-3000 \mathrm{kWh} / \mathrm{m}^{3} /$ order range for the different analysed dyes and are considerably higher than the efficiency values of discolouration of $25 \mathrm{mg} / \mathrm{L}$ of $\mathrm{RB} 5$ with $\mathrm{TiO}_{2} / \mathrm{UV}-\mathrm{A}$ LED radiation reported in this research work $\left(359 \mathrm{kWh} / \mathrm{m}^{3} /\right.$ order $)$.

The efficiency of UV-A LEDs was calculated with the same set of experiments assisted with solar radiation. Solar radiation treatments had discolouration rates between 4 and 72 times faster than those of UV-A LED radiation treatments carried out in the first photo-system $\left(23 \mathrm{~W} / \mathrm{m}^{2}\right)$. These values mean that the first UV-A LED photo-system could not match solar radiation in terms of irradiance. However, the second and more powerful UV-A LED photo-system results lead solar radiation yields. At this point, is also worth highlighting one potential advantage of UV-A LED radiation versus solar radiation-the possibility of continuous usage $24 \mathrm{~h}$ per day, 365 days per year, independently of climate conditions and the season of the year.

Regarding the treatments combining $\mathrm{TiO}_{2}$ and $\mathrm{H}_{2} \mathrm{O}_{2}$, the addition of a correct concentration of $\mathrm{H}_{2} \mathrm{O}_{2}$, when compared to $\mathrm{TiO}_{2} /$ UV-A LED process, is better and faster in almost all the situations, as can be seen in Figs. 2 and 4 and through comparing $k$ values and $t_{1 / 2}$ in Table $1 \mathrm{~A}$. In general, an increase in the concentration of hydrogen peroxide enhances the discolouration rate of RB5 dye, although there are some exceptions. For instance, when the treatments were carried out in continuous mode, the degradation rate increased as a function of hydrogen peroxide concentration to some extent. Thus, the fastest degradation rate $\left(k=0.0674 \mathrm{~min}^{-1}\right)$ was reached with $4.41 \mathrm{mM}$ of $\mathrm{H}_{2} \mathrm{O}_{2}$ and $1 \mathrm{~g} / \mathrm{L}$ of $\mathrm{TiO}_{2}$, instead of $17.64 \mathrm{mM}$ of $\mathrm{H}_{2} \mathrm{O}_{2}\left(k=0.0135 \mathrm{~min}^{-1}\right)$. In addition, and excess of $\mathrm{TiO}_{2}$ and $\mathrm{H}_{2} \mathrm{O}_{2}$ get worse the rate degradation of dye, reaching better results with $0.5 \mathrm{~g} / \mathrm{L}$ of $\mathrm{TiO}_{2}$ and $17.64 \mathrm{mM}$ of $\mathrm{H}_{2} \mathrm{O}_{2}$ $\left(k=0.0217 \mathrm{~min}^{-1}\right)$ than the same experiment with $1 \mathrm{~g} / \mathrm{L}$ of $\mathrm{TiO}_{2}$ $\left(k=0.0135 \mathrm{~min}^{-1}\right)$. These results could be the consequence of scattering and shielding by suspended catalyst [36]. In batch treatments, the behaviour of hydrogen peroxide in combination with $\mathrm{TiO}_{2}$ and UV-A LED radiation is totally different from that observed in continuous mode. In the latter case, the presence of $\mathrm{H}_{2} \mathrm{O}_{2}$ also increases the rate of degradation, however the increase of the amount of $\mathrm{H}_{2} \mathrm{O}_{2}$ in the system does not improve the rate of degradation, and the best results are acheived with the lowest concentration of $\mathrm{H}_{2} \mathrm{O}_{2}(1.76 \mathrm{mM})$.

Some authors have reported that the addition of hydrogen peroxide to photocatalytic treatment enhances the yield of the treatments, either through the inactivation of microorganisms $[37,38]$ or through the removal of persistent organic micropollutants [39]. However, an excess of $\mathrm{H}_{2} \mathrm{O}_{2}$ is detrimental to the final discolouration rate, and other studies confirm the results obtained from the $\mathrm{TiO}_{2} / \mathrm{H}_{2} \mathrm{O}_{2}$ treatments performed in this research work. Lanao et al. showed that the $\mathrm{TiO}_{2} / \mathrm{H}_{2} \mathrm{O}_{2}$ treatment, ( $0.04 \mathrm{mM} \mathrm{H}_{2} \mathrm{O}_{2}, 1 \mathrm{~g} / \mathrm{L} \mathrm{TiO}_{2}$ and UV-vis radiation) did not achieve a higher level of inactivation than photocatalysis treatment $(1 \mathrm{~g} / \mathrm{L}$ $\mathrm{TiO}_{2}$ and UV-vis radiation) in the removal of microorganisms (Enterococcus sp.) spiked in fresh water samples [31]. Thus, if there is an excess of hydrogen peroxide, it can also act as a ${ }^{\bullet} \mathrm{OH}$ radical scavenger or form peroxocompounds on the $\mathrm{TiO}_{2}$ surface, thus prejudicing the photocatalytic process [33].

\section{Conclusions}

After using two UV-A LED photo-systems, the following conclusions can be drawn from $\mathrm{TiO}_{2}$ and $\mathrm{TiO}_{2} / \mathrm{H}_{2} \mathrm{O}_{2}$ studies of a model compound of textile wastewater-Reactive Black 5 (RB5) discolouration:

- UV-A LEDs are an attractive alternative to conventional UV lamps, because they are more ecofriendly, have a low operational cost, and high energy efficiency.

- $\mathrm{TiO}_{2} / \mathrm{UV}-\mathrm{A}$ LED processes lead to complete discolouration of Reactive Black 5 dye with both photo-systems. The degradation rate of the dye increases with the increase of UV irradiance and with the addition of hydrogen peroxide in an adequate dosage. However, an excessive dosage of hydrogen peroxide generates unproductive reactions and scavenger effects, decreasing the degradation rate of the treatment.

- Photocatalysis assisted by the second UV-A LED photo-system was almost as fast as the discolouration of RB5 assisted by solar radiation.

- Thus, this method has the potential to overcome some significant limitations of solar photocatalysis, such as weather 
conditions and sunlight exposure time, using a low-cost, relatively eco-friendly photo-system, which, in spite of treatments carried out in continuous mode being slightly slower than the treatments in batch mode, could provide a serious option for industrial wastewater treatment plants.

\section{Acknowledgments}

The authors are grateful to Fundação para a Ciência e a Tecnologia (FCT) and FEDER for the financial support provided to CQVR through PEst-C/QUI/UI0616/2014.

\section{Appendix A. Supplementary data}

Supplementary data associated with this article can be found, in the online version, at http://dx.doi.org/10.1016/j.jece.2015.10.019.

\section{References}

[1] K.T. Chung, S.E.J. Stevens, Degradation of azo dyes by environmental microorganisms and helmints, Environ. Toxicol. Chem. 54 (1993) 435-441.

[2] K.T. Chung, S.E.J. Stevens, C.E. Cerniglia, The reduction of azo dyes by the intestinal microflora, Crit. Rev. Toxicol. 18 (1992) 175-190.

[3] Y. Anjaneyulu, N. Sreedhara-Chary, S. Suman-Raj, Decolourization of industrial effluents -available methods and emerging technologies -a review, Rev. Environ. Sci. Technol. 4 (2005) 245-273.

[4] A.D. Dias, A. Sampaio, R.M. Bezerra, Environmental Applications of Fungal and Plant Systems: Decolourisation of Textile Wastewater and Related Dyestuffs. Environmental Bioremediation Technologies, Springer Berlin, Heidelberg, 2007, pp. 445-4463.

[5] A. Houas, H. Lachheb, M. Ksibi, E. Elaloui, C. Guillard, J.M. Herrmann, Photocatalytic degradation pathway of methylene blue in water, Appl. Catal. B: Environ. 31 (2001) 145-157.

[6] N.M. Mahmoodi, M. Arami, Bulk phase degradation of acid red 14 by nanophotocatalysis using immobilized titanium (VI) oxide nanoparticles, J. Photochem. Photobiol. A: Chem. 182 (2006) 60-66.

[7] Directive 2002/61/EC of the European parliament and of the council of 19 July 2002 amending for the nineteenth time Council Directive 76/769/EEC relating to restrictions on the marketing and use of certain dangerous substances and preparations (azocolourants).

[8] M.S. Lucas, P.B. Tavares, J.A. Peres, J.L. Faria, M. Rocha, C. Pereira, C. Freire, Photocatalytic degradation of Reactive Black 5 with $\mathrm{TiO}_{2}$-coated magnetic nanoparticles, Catal. Today 209 (2013) 116-121.

[9] S.M. Ghoreishian, K. Badii, M. Norouzi, A. Rashidi, M. Montazer, M. Sadeghi, M. Vafaee, Decolorization and mineralization of an azo reactive dye using loaded nano-photocatalysts on spacer fabric: kinetic study and operational factors, J. Taiwan Inst. Chem. Eng. 45 (5) (2014) 2436-2446.

[10] M.S. Lucas, J.A. Peres, Decolorization of the azo dye Reactive Black 5 by Fenton and photo-Fenton oxidation, Dyes Pigm. 71 (3) (2006) 236-244.

[11] M.S. Lucas, J.A. Peres, Degradation of Reactive Black 5 by Fenton/UV-C and ferrioxalate $/ \mathrm{H}_{2} \mathrm{O}_{2} /$ solar light processes, Dyes Pigm. 74 (3) (2007) 622-629.

[12] C. Zhang, L. Gu, Y. Lin, Y. Wang, D. Fu, Z. Gu, Degradation of X-3B dye by immobilized $\mathrm{TiO}_{2}$ photocatalysis coupling anodic oxidation on BDD electrode, J. Photochem. Photobiol. A 207 (1) (2009) 66-72.

[13] A. Khanna, V.K. Shetty, Solar light induced photocatalytic degradation of Reactive Blue 220 (RB-220) dye with highly efficient $\mathrm{Ag} @ \mathrm{TiO}_{2}$ core-shell nanoparticles: a comparison with UV photocatalysis, Sol. Energy 99 (2014) 67-76.

[14] M.P. Ormad, N. Miguel, M. Lanao, R. Mosteo, J.L. Ovelleiro, Effect of application of ozone and ozone combined with hydrogen peroxide and titanium dioxide in the pesticides removal from water, Ozone-Sci. Eng. 32 (2010) 25-32.

[15] N. Miguel, Estudio de la eliminación de plaguicidas presentes habitualmente en aguas de la cuenca del Ebro mediante procesos de oxidación avanzada. Doctoral Thesis, University of Zaragoza (Spain), 2010.

[16] E.S. Elmolla, M. Chaudhuri, Degradation of the antibiotics amoxicillin, ampicillin and cloxacillin in aqueous solution by the photo-Fenton process, J. Hazard. Mater. 172 (2009) 1476-1481.
[17] E.S. Elmolla, M. Chaudhuri, Comparison of different advanced oxidation processes for treatment of antibiotic aqueous solution, Desalination 256 (2010) 43-47.

[18] C. Pulgarin, J. Kiwi, V. Nadtochenko, Mechanism of photocatalytic bacterial inactivation on $\mathrm{TiO}_{2}$ films involving cell-wall damage and lysis, Appl. Catal. $\mathrm{B}$ Environ. 128 (2012) 179-183.

[19] M. Agulló-Barceló, M.I. Polo-López, F. Lucena, J. Jofre, P. Fernández-Ibánez Solar advanced oxidation processes as disinfection tertiary treatments for real wastewater: implications for water reclamation, Appl. Catal. B Environ. 136-137 (2013) 341-350.

[20] S. Malato, P. Fernández-Ibáñez, M.I. Maldonado, J. Blanco, W. Gernjak, Decontamination and disinfection of water by solar photocatalysis: recent overview and trends, Catal. Today 147 (2009) 1-59.

[21] J.P. Ghosh, R. Sui, C.H. Langford, G. Achari, C.P. Berlinguette, A comparison of several nanoscale photocatalysts in the degradation of a common pollutant using LEDs and conventional UV light, Water. Res. 43 (18) (2009) 4499-4506.

[22] H. Hossaini, G. Moussavi, M. Farrokhi, The investigation of the LED-activated FeFNS- $\mathrm{TiO}_{2}$ nanocatalyst for photocatalytic degradation and mineralization of organophosphate pesticides in water, Water Res. 59 (2014) 130-144.

[23] H. Eskandarloo, A. Badiei, M.A. Behnajady, G.M. Ziarani, UV-LEDs assisted preparation of silver deposited $\mathrm{TiO}_{2}$ catalyst bed inside microchannels as a high efficiency microphotoreactor for cleaning polluted water, Chem. Eng. J. 270 (2015) 158-167.

[24] E. Repo, S. Rengaraj, S. Pulkka, E. Castangnoli, S. Suihkonen, M. Sopanen, M. Sillanpää, Photocatalytic degradation of dyes by CdS microspheres under near UV and blue LED radiation, Sep. Purif. Technol. 120 (2013) 206-214.

[25] M.H. Rasoulifard, M. Fazli, M.R. Eskandarian, Performance of the lightemitting-diodes in a continuous photoreactor for degradation of Direct Red 23 using UV-LED $/ \mathrm{S}_{2} \mathrm{O}_{8}{ }^{2-}$, J. Ind. Eng. Chem. 24 (2015) 121-126.

[26] I. Carra, P. Sánchez, J.A. erez, S. Malato, O. Autin, B. Jefferson, P. Jarvis, Application of high intensity UVC-LED for the removal of acetamiprid with the photo-Fenton process, Chem. Eng. J. 264 (2015) 690-696.

[27] S. Verma, M. Sillanpää, Degradation of anatoxin-a by UV-C LED and UV-C LED/ $\mathrm{H}_{2} \mathrm{O}_{2}$ advanced oxidation processes, Chem. Eng. J. 274 (2015) 274-281.

[28] K. Natarajan, T.S. Natarajan, H.C. Bajaj, R.J. Tayade, Photocatalytic reactor based on UV-A LED $/ \mathrm{TiO}_{2}$ coated quartz tube for degradation of dyes, Chem. Eng. J. 178 (2011) 40-49.

[29] T. Rojviroon, A. Laobuthee, S. Sirivithayapakorn, Photocatalytic activity of toluene under UV-A LED light with $\mathrm{TiO}_{2}$ thin films, Int. J. Photoenergy (2012), doi:http://dx.doi.org/10.1155/2012/898464.

[30] B. Ohtani, O.O. Prieto-Mahaney, D. Li, R. Abe, What is Degussa (Evonik) P25? Crystalline composition analysis, reconstruction from isolated pure particle and photocatalytic activity test, J. Photochem. Photobiol. A 216 (2-3) (2010) 179-182.

[31] M. Lanao, M.P. Ormad, R. Mosteo, J.L. Ovelleiro, Inactivation of Enterococcus sp. by photolysis and $\mathrm{TiO}_{2}$ photocatalysis with $\mathrm{H}_{2} \mathrm{O}_{2}$ in natural water, Sol. Energy 86 (2012) 619-625.

[32] J.R. Bolton, K.G. Bircher, W. Tumas, C.A. Tolman, Figures-of-merit for the technical development and application of advanced oxidation technologies for both electric- and solar-driven systems, Pure Appl. Chem. 73 (4) (2001) 627-637.

[33] M. Kositzi, I. Poulios, S. Malato, J. Caceres, A. Campos, Solar photocatalytic treatment of synthetic municipal wastewater, Water Res. 38 (2004) 11471154.

[34] A.R. Khataee, M.N. Pons, O. Zahra, Photocatalytic degradation of three azo dyes using immobilized $\mathrm{TiO}_{2}$ nanoparticles on glass plates activated by UV light irradiation: influence of dye molecular structure, J. Hazard. Mater. 168 (1) (2009) 451-457.

[35] C. Yu, C. Wu, T. Ho, P.K. Andy Hong, Decolorization of C. I. Reactive Black 5 in $\mathrm{UV} / \mathrm{TiO}_{2}$, UV/oxidant and $\mathrm{UV} / \mathrm{TiO}_{2}$ /oxidant systems: a comparative study, Chem. Eng. J. 158 (3) (2010) 578-583.

[36] C.M. So, M.Y. Cheng, J.C. Yu, P.K. Wong, Degradation of azo dye Procion Red MX-SB by photocatalytic oxidation, Chemosphere 46 (2002) 905-912.

[37] P.S. Hartmann, A. Eisenstark, Synergistic killing of Escherichia coli by near-UV radiation and hydrogen peroxide: distinction between RecARepairable and RecA-Nonrepairable damage, J. Bacteriol. 133 (1978) 769-774.

[38] A.G. Rincón, C. Pulgarin, Effect of pH, inorganic ions, organic matter and $\mathrm{H}_{2} \mathrm{O}_{2}$ on E. coli $\mathrm{K} 12$ photocatalytic inactivation by $\mathrm{TiO}_{2}$. Implications in solar water disinfection, Appl. Catal. B Environ. 51 (2004) 283-302.

[39] N. Miguel, M.P. Ormad, R. Mosteo, J.L. Ovelleiro, Photocatalytic degradation of pesticides in natural water: effect of hydrogen peroxide, Int. J. Photoenergy (2012), doi:http://dx.doi.org/10.1155/2012/371714. 